\title{
Kitlesel Göç, Sosyal Kabullenme ve Uyum Bağlamında Türkmen İşçilerin Deneyimleri
}

\author{
DOI: 10.26466/opus.932531
}

\author{
Mustafa Karataș ${ }^{*}$ Veli Duyan** \\ * Dr., İstanbul Sabahattin Zaim Üniversitesi, Sağlık Bilimleri Fakültesi,İstanbul/Türkiye \\ E-Posta: mustafa.karatas@izu.edu.tr \\ ORCID: $\quad$ 0000-0002-0998-2552 \\ ** Prof. Dr.,Ankara Üniversitesi, Sağlık Bilimleri Fakültesi, Ankara/Türkiye \\ E-Posta: vduyan@health.ankara.edu.tr \\ ORCID: $\quad$ 0000-0003-4316-5756
}

\section{Öz}

Bu araştırmanın amacl, kitlesel göç ile Kuzey Irak'tan Türkiye'ye gelen Türkmen işçilerin çalışma deneyimlerini öğrenmek; baş etme stratejilerini anlamak; uyum, sosyal kabullenme kavramları kapsamında mevcut durumu değerlendirmektir. Nitel araştırma yöntemlerinden yararlanılarak gerçekleştirilen çalışmada, iş deneyimi yaşamış, yaşları 18 ve üstü olan, kitlesel göç ile Türkiye'ye gelmiş 40 Türkmen ile görüşmeler gerçekleştirilmiştir. Durum çalışması niteliğinde gerçekleştirilen araştırmanın verileri MAXQDA 2020 programı ile analiz edilmiştir. Araştırmada elde edilen verilerin analizi sonucunda Türkmen göçmenlerin iş deneyimleri ile ilgili olarak Türkiye'deki meslekleri, iş hayatlarında yaşadıkları olumlu ya da olumsuz tecrübeler, çalışma hayatlarındaki sosyal sorunlar gibi konularda tespitler yapılmaya çalş̧ılmıştır. Iraklı Türkmenlerin iş hayatında olumlu koşulların sağlanması ile sosyal hayata daha rahat uyum sağlayacakları anlaşılmıştır. Genel olarak iş bulma konusunda dil ve mesleki yetersizliklerin önemli olduğu anlaşılmıştır. Bu kapsamda göç yönetiminde mesleki değerlendirme birimlerinin kurularak göç öncesi ve göç sonrası meslek eşleştirmelerinin yapılarak gö̧̧menlerin istihdam programlarına dahil edilmesi, gö̧̈menlerin meslek değerlendirmelerinin yapılacağı ön değerlendirme sistemlerinin kurulması, meslek verilerinin istihdamın yaygınlaştırılması için kurum ve kuruluşlarca paylaşılması gerektiği, meslek edindirme okullarının ve kurslarının Türkçe öğretecek şekilde dizayn edilerek göçmenlere ulaştırılması, işverenler ile koordinasyon kurularak meslek eleman açı̆̆ının tespit edilmesi, iş piyasasında ya da meslek edindirme kurslarında olan göçmenler için psikososyal müdahalelerin geliştirilmesi, uyum ve sosyal kabullenme çerçevesinde mikro, mezzo ve makro çalışmaların yapılması önerilmektedir.

Anahtar Kelimeler: Göç, İş Deneyimleri, Kitlesel Göç, Sosyal Kabullenme, Türkmen, Uyum. 


\title{
The Experiences of Turkmen Workers' Access to Labor Market in the Context of Mass Influx, Social Acceptance and Adaptation
}

*

\begin{abstract}
The study aims to learn with a mass influx from northern Iraq to Turkey Turkmen work experience, to understand their coping strategies, compliance, due diligence is to make the scope of social acceptance of concepts. In the study conducted qualitative research utilizing the method of work experience lived, ages 18 and older, with a mass influx came to Turkey with 40 Turkmen forms, semi-structured interviews have seen the application forms were applied.As a result of the research, it was observed that the participants had a desire to quickly access the labor market due to the adverse situations they experienced during the migration phases, mainly because they encountered severe economic problems when they came to the target country. The existence of more than one social problem has also been identified in the Turkmen's work experience. It is understood that if favorable conditions are provided in the business life of the Turkmen, there will be more convenient in terms of social acceptance and harmony. In general, it was observed that asylum-seekers with language difficulties could not adapt to finding employment and everyday living conditions. Providing sustainable job opportunities, ensuring environment-person compliance, and creating employment services specifically for asylum seekers are of great importance.
\end{abstract}

Key Words: Adaptation, Mass Influx, Migration, Social Acceptance, Turkmen, Work Experiences. 


\section{Giriş}

Son yıllarda meydana gelen ve süreklilik arz eden, küreselleşme ve bölgesel eşitsizlikler nedeniyle geri kalmış ülkelerden gelişmekte olan veya gelişmiş ülkelere göç hareketinin olduğu gözlemlenmektedir. Dünya Göç Örgütü (İM), tarafından yayımlanan 2020 Dünya Göç Raporu'nda, ülkelerinde yaşanan şiddet ve anlaşmazlık dolayısıyla yerinden edilen insanların sayısı 41,3 milyon olmuştur. Bu sayı 1998 yılından beri kaydedilen en yüksek rakamdır. Suriye, yerinden edilmelerde en fazla sayıya ulaşan ülkedir (6.1 Milyon). Suriye'yi Kolombiya (5.8 Milyon) ve Kongo Demokratik Cumhuriyeti (3.1 Milyon) izlemektedir.

Türkiye, jeopolitik konumu ve Avrupa'ya geçişte köprü görevi görmesi nedeniyle göç dalgalarına maruz kalabilmektedir. Özellikle Suriye ve Irak'ta meydana gelen iç karışıklıklar, Türkiye'ye yönelik kitlesel göç hareketlerinin başlamasına neden olmuştur. Göç akımlarındaki artış ve Türkiye'ye giren sı̆̆ınmacı sayılarındaki yükseliş, göç yönetiminde profesyonelleşmeyi de beraberinde getirmiştir.

Iraklı Türkmenlerin kendi ülkelerinde yaşanan karışıklıklardan dolayı yerlerinden edildikleri ve Türkmenlerin yurtdışına göç hareketinde sınır komşusu olması nedeni ile en çok tercih ettikleri ülkenin Türkiye olduğu bilinmektedir. Bu durumun başlıca sebepleri arasında Irak'ta yaşanan iç anlaşmazlıklar ile birlikte, eğitim dilinin Türkçe olmasının yanında coğrafi yakınlık, iş piyasası ile ilgili alternatiflerin varlığı, insani yaşam koşullarının Türkiye'de daha iyi olması, kültürel köken benzerliklerinin olması ifade edilebilir (Gündüz ve Kalayc1, 2016).

\section{Göçmenler ve Çalışma Hayatı}

Yeni gelen göçmenlere iş bulmak, topluma uyum konusunda önemli bir rol oynamaktadır. Avrupa ülkelerinde göçmenlerin sosyal refah sistemlerine dahil olmaları, dışlanma veya ötekileştirme gibi oluşabilecek sosyal sorunların önüne geçmektedir (Hooper, Desiderio, Salant, 2017).

İş piyasasına uyum, sosyo-ekonomik uyumun en önemli basamağıdır. Bazı ülkelerde çalışma ve ikamet izni temel haklara erişim için en önemli araçlardandır. İş piyasasına erişim, göçmen açısından bir ülkenin toplumuna katılımda (gelinen ülkenin dil bilgisine sahip olmak vb.) 
önemli olmakla birlikte göçmenin yeterlilikleri, eğitim seviyesi, barınma ve mesleki eğitime erişiminde önemli rol oynamaktadır (Lodovici, 2010). Bu bağlamda, sosyo-ekonomik düzeydeki uyumun kritik bir noktası olan iş piyasasına erişimin sosyal işlevselliğin sağlanması açısından önem arz ettiği görülmektedir. Sosyal uyumun olmaması durumunda, göçmenlerin yoksulluğa sürüklenme risklerinin olduğu, göçmenlerde yoksulluk kültürünün oluştuğu değerlendirilebilir (Wang ve Fan, 2012).

Uluslararası Çalışma Örgütü'nün 2015 yılında yapmış olduğu göçmen istatistikleri çalışmasına göre, dünyada tahmini olarak 150,3 milyon göçmen çalışan vardır. Bunların 11,5 milyonu ev işlerinde çalışmaktadır.

OECD 2017 Göç Raporunda göç hareketleri sonucu G20 ülkelerinin iş piyasasına katkısı büyümüştür ancak göç çalışanlarının uyumunun sağlanmasındaki zorluklar ve dirençler ile ev sahibi ülkelerin ihtiyaç duyduğu meslekler ile göçmenlerin meslek gruplarının farklılıkları bu konuda çeşitli problemleri beraberinde getirdiği yer almış, ideal uygulamalar olması için üç bölümlü planlama yapılmıştır: (1) göçmenlerin ve sı̆̆ınmacıların yeteneklerinin gelişimi, değerlendirmesi ve katılımının sağlanmasının getireceği etki, (2) Göçmen çalışanların istismarının ve ayrımcı davranışlar sergilenmesinin önlenmesi, (3) Göç alan-veren ülkelerle diyaloğun olması ve sivil toplum kuruluşları ile irtibatın iyi olması.

\section{Uyum ve Sosyal Kabullenme}

Günümüzde devletler kendi ekonomilerini güçlendirmek, sosyal ihtiyaçlarını karşılamak, insani yardım, tarihi bağlar, sınırlarını kontrol etmede yaşanan yetersizlikler gibi farklı nedenlerle isteyerek ve/veya istemeden göçmen kabul etmektedir. Uyum kavramı, toplumsal yapının görüşlerini yansıtan kamu politikaları aracılığı ile normatif olarak açıkça ifade edilmektedir (Şeker, 2015).

Göçmenlerin uyumları farklı araştırmacılar tarafından (Searle ve Ward 1990; Sam, Vedder, Leikbind Neto ve Virta, 2008; Ward ve Kenedy, 1994) irdelenmiş ve göçmenlerin uyumu iki boyutlu olarak değerlendirilmiştir. Bunlardan ilki; psikolojik uyum, ikinci ise sosyo-kültürel uyum olarak adlandırılır. Stres ve stresle başa çıkma mekanizmaları, uyumun duygusal ve ruhsal etkilerinin önemli bir bileşenidir. Bu boyutta uyumun psikolojik 
boyutunun önemi büyüktür (Abu-Rayya, 2013). Berry, ekonomik uyumunda diğer uyum boyutlarının yanında olması gerektiğini savunarak, yeni dahil olunan kültürel ortamda bireyin işinin etkili ve doyumlu şekilde yaşamasına katkı sağlamasını savunmuştur (Berry, 1997 akt: Şeker, 2015). 2008 yılında yapılan bir araştırmada sığınmacıların göç sonrasındaki dört ana zorluğu deneyimledikleri anlaşılmıştır: Çevre idaresi, Finansal zorluklar, Sosyal izolasyon ve Algılanan ırkçılığın etkisi (Khawaja vd. 2008).

Sosyal kabullenme, bir olgunun ya da yaşama biçiminin, toplumun dinamiklerine uyum aşamasında, beraber yaşanılacak bireylerin farkındalık düzeylerinin arttırılması, bireyin ya da olgunun yaşamını sürdürmesi ve toplum tarafından herhangi bir rahatsızlık yaşanmaksızın hayati faaliyetlerine devam ettirilmesi olarak tanımlanabilir. Bu konu her ne kadar "uyum" kavramı ile özdeşleştirilmeye çalışılsa da bazı noktalarda farklılıklar gözlemlenebilmektedir. Uyumun, sosyal kabullenmenin tamamlanmasında bir araç ya da süreç olduğu düşünüldüğünde birbirleri ile doğrudan ilişki içinde oldukları söylenebilir.

Türkiye'ye kitlesel göçlerle gelen Türkmen göçmenlerin sosyal kabullenme ve uyum bağlamında yaşadıkları deneyimlerin ekolojik boyutta neler olduğunun belirlenmesi bu araştırmanın problemini oluşturmaktadır.

Bu çalışmada kitlesel göç ile Kuzey Irak'tan Türkiye'ye gelen ve çalışan Türkmenlerin çalışma deneyimleri, ekonomik hayata katılımda baş etme stratejileri, uyum, sosyal kabullenme ve kitlesel göçler kapsamında incelenmiştir. Bununla birlikte, kültürleşme, çok kültürlülük, sosyal kimlik gibi konular irdelenerek araştırma odağı ile ilgili olarak geniş çerçevede değerlendirme yapılmıştır. Bu araştırmanın amacı, Iraklı Türkmenlerin iş piyasasında ne tür deneyimler yaşadıkları, hangi kaynaklardan, hizmetlerden ve fırsatlardan yararlandıklarını ve ihtiyaç duydukları sosyal hizmetlerin neler olduğunu anlamaktır.

\section{Yöntem}

Kitlesel göç, sosyal kabullenme ve uyum bağlamında Türkmen işçilerin çalışma deneyimleri ile ilgili olarak araştırma modeli, veri toplama 
araçları ile süre ve olanaklar bu bölümde ele alınmıştır. Araştırma Eylül 2019- Ağustos 2020 tarihleri arasında gerçekleştirilmiştir.

Araştırmada nitel araştırma yöntemi kullanılmış olup, araştırma deseni olarak 'durum çalışması' kullanılmıştır. Bu çalışmada, Türkmen işçilerin çalışma deneyimleri, sosyal kabullenme ve uyum odağında değerlendirilmiştir. $\mathrm{Bu}$ nedenle çalışma fenomenolojik bir temele dayandırılmıştır. Fenomenolojik analizde, araştırmacı ile katılımcılar arasında etkileşim sürecinin analizi söz konusudur. Fenomenolojik analizi kullanan araştırmacı, uygulamalarında, katılımcıların söyledikleri kapsamında onların düşüncelerini ve duygularını değerlendirmeye çalışmaktadır (Smith ve Eatough, 2007).

Araştırmanın evrenini Türkiye'de çalışma deneyimleri olan Türkmenler oluşturmaktadır. Burada maksimum çeşitlilik bir ilke olarak belirlenmiş olup, kartopu örneklem kullanılmıştır. Araştırmanın amacına uygun olarak katılımcların davet edilmesi için bazı şartlar ya da ölçütler belirlenmiştir. Her ne kadar örneklem kartopu olsa da, katılımcıların araştırma için uygun koşulları sağlayıp sağlamadığına dikkat edilmiştir. 2011 krizinden önce gelerek Türkiye'ye yerleşen Türkmenlerin araştırma kapsamına alınmamıştır. Bu kapsamda araştırmaya dahil edilecek katılımcılarda şu özellikler aranmıştır:

1. Kitlesel göç ile Türkiye'ye gelmiş olmak,

2. Çalışmanın yapıldığı dönemde 18 yaş ve üzerinde olmak,

3. İş deneyimine (işçi veya işveren) sahip olmak,

4. Türkmen olmak (2011 yılından sonra savaş nedeni ile Türkiye'ye gelmiş olmak)

Araştırmada görüşme yapılan kişilere, alanda destek sağlayan ve akademik araştırmalar yapan "İpek Yolu Toplumları ve Kültürleri Derneği" aracılığı ile erişilmiştir. Söz konusu Dernek ile gerekli yazışmalar yapılmış, katılımcılara ulaşmak ve dernek imkanlarından yararlanmak için gerekli izin yazısı alınmıştır. İpek Yolu Toplumları ve Kültürleri Derneği faal olarak çalışmakta olup, göç, siyaset ve uluslararası ilişkiler bağlamında da çeşitli illerde etkinliklerde bulunmaktadır. Derneğe kayıtlı olan Iraklı Türkmenlerin toplam sayısı gizlilik gerekçesi ile öğrenilememiştir.

Bütün katılımcılara gönüllü katılımları ile ilgili olarak şartlar anlatılıış ve bilgilendirilmiş onamları kendi ana dillerinde sunulmuştur. 
Katılımcıların Türkçe yazılmış Bilgilendirilmiş Onam'ı okumalarında ve anlamalarında herhangi bir sıkıntı görülmemiştir. Araştırmanın odağına hizmet edecek, alt görüşme zaman limiti 45 dakika olarak belirlenmiştir. Araştırmanın şartlarına uygun 40 katılımcı ile görüşmeler gerçekleştirilmiştir. Araştırma kapsamında katılımcıların kimlik bilgilerinin ve ifadelerinin gizlilik kapsamında korunmasına önem verilmiştir.

\section{Veri Toplama Araçları}

Türkmenlerin çalışma deneyimleri ile ilgili yapılan görüşmelerde, yarı yapılandırılmış görüşme formu kullanılmıştır. Yarı yapılandırılmış görüşme formu gerekli literatür taraması ve alan bilgilerinin derlenmesi sonucunda oluşturulmuştur. İki bölümden oluşan formun İlk bölümünde katılımcların kişisel bilgileri ile ilgili açık uçlu sorular yer almaktadır. Formun ikinci bölümünde ise göç öncesindeki/ göç sırasında/ sosyoekonomik durum, mesleki beceriler ve iş piyasasına erişim hakkındaki deneyimler ve düşünceler, Türkiye'de ki sosyo-ekonomik deneyimler, yararlanılan sosyal yardımlar ve sosyal hizmetler, Türkiye'de çalışma deneyimleri, sosyal kabullenme ve uyum ile ilgili soruları içermektedir. Soru formunda çalışma deneyimleri, sosyal kabullenme, uyum ve sosyal kabullenme hem de uyum ile ilgili olarak on iki soru bulunmaktadır.

\section{Veri Oluşturma Süreci}

Araştırma kapsamında veri oluşturma sürecinde derinlemesine görüşmeler yapılmıştır. Derinlemesine görüşmelerde katılımcıların iş tecrübeleri, göç deneyimleri, göç deneyimlerinin iş piyasasına girişlerini nasıl etkilediği, göç evreleri süresince iş piyasası ile ilgili gözlemleri elde edilmeye çalışılmıştır. Görüşmelerde katılımcıların Türkçe okur yazarlığının olması sebebi ile tercümana ihtiyaç duyulmamıştır. Araştırmaya katılım onamlarının katılımcılar tarafından net ve iyi derecede anladıklarından (onamın yüksek sesle okunması istenmiştir) emin olunmuştur.

Görüşme sürecine başlamadan önce daha önce Türkmenlerin çalıştığ1 birkaç işveren ile görüşme yapılmıştır. Görüşmelerde iş yeri sahiplerinin 
bazılarının görüşme talebini olumlu karşıladığ1; bazılarının ise görüşme taleplerine olumsuz yanıt verdikleri gözlemlenmiştir. Gizlilik ilkesine önem veren işverenlerin bu konuda hassas davrandıkları gözlemlenmiş, yapılan ön görüşmeler ile iş yeri sahiplerinin gözünden Türkmenlerin iş deneyimleri anlaşılmaya çalışılmıştır.

İpek Yolu Toplumları ve Kültürleri Derneği ve Iraklı Türkmenler Yardımlaşma Derneği yetkilileri ile de birtakım görüşmeler gerçekleştirilmiştir. Söz konusu dernekler aracılığı ile birkaç Türkmen ile ön görüşmeler yapılmıştır. Iraklı Türkmenler Yardımlaşma Derneği yetkilileri ile görüşmede dernek faaliyetleri ile ilgili bilgi edinilmiştir. Bu kapsamda bütün Türkmenlere ulaşamadıklarını söyleyen dernek yetkilileri, genel olarak erzak yardımlarının yapıldığını belirtmişlerdir.

Araştırmacı, görüşmelerin sağlıklı ortamda yapılması, görüşmelerin güvenilirliği ve gizliliği açısından rahatlıkla kullanabileceği, ulaşımın rahat olacağı ve kolaylıkla katılımcıların işlerine dönebilecekleri, Ankara'da merkezi konumlu bir ofisi kendi imkanları ile altı aylığına kiralamıştır. Araştırmacı görüşmeleri, bu ofiste gerçekleştirmiştir.

Görüşmelere katılım ile ilgili olarak, özellikle kartopu örneklem kapsamında katılımcıların mahallesinde araştırma için uygun şartları taşıdığı düşünülen bazı kişilerin, araştırmaya katılmayı kabul etmedikleri gözlemlenmiştir.

Katılımcılardan elde edilen bilgiler ışığında, Türkmen kadınların genellikle tekstil atölyelerinde aile geçimine katkıda bulunmak için çalıştıkları, aile yapısı olarak kadınların çalışma durumuna olumsuz yaklaşıldığı anlaşılmıştır. Bu nedenle araştırmacı, kadın Türkmen çalışanların da araştırmaya dahil edilmesi için araştırmaya katılan diğer Türkmenlerin desteğini ve yardımlarını istemiştir.

Türkmen işçilerin iş deneyimlerinin, çalıştıkları iş alanına göre değiştiği, Türkmen işçilerin uyum ve sosyal kabullenme sürecine iş deneyimlerinin etkisinin olduğu varsayılmaktadır.

Katılımcllar ile ilgili yapılan statü analizinde hepsinin "Uluslararası Koruma Başvuru Sahibi" statüsünde oldukları, güvenlikleri ve kişisel bilgilerinin koruma altında bulunması kapsamında gizlilik prensibi ön planda tutularak çalışma gerçekleştirilmiştir. Bu kapsamda araştırmada bazı sınırlılıklar oluşmuştur. Bu sınırlılıklar aşağıda belirtilmiştir: 
1. Sinırlılıklardan ilki, ses kayıt cihazının kullanılamamasıdır. Bu bakımdan araştırmacı katılımcılar ile yaptığı görüşmeleri not ederek kayıt altına almıştır. Bundan dolayı araştırmacı, görüşme devam ederken aynı zamanda not tutmaya çalışmış ve bu durum katılımcıların bazı ifadelerinin kaybolmasına neden olmuştur.

2. Araştırmayla ilgili bir diğer sınırlılık ise kadın katılımcıların araştırmaya katılmamış olmasıdır. Türkmenlerin kültürel aile yapısı gereği kadınları çalıştırmamaları ya da çalışmak zorunda kalan kadın katılımcıların katılmaya gönüllü olmamaları cinsiyet bakımından sınırlılık oluşturmuştur.

3. Bir diğer sınırlılık, katılımcıların çalışma koşullardır. İş yerlerinden izin alamayan ya da iş saatini dolduramayan katılımcların görüşmelere gelmesinde sıkıntılar olmuştur. Bundan dolayı bazı görüşmeler geç gerçekleşmiş ya da bazıları da hiç olmamıştır.

4. Katılımcıların kendileri ile ilgili bilgi vermekten çekinmeleri bir başka sınırlılık olarak tespit edilmiştir. Bazı Türkmenler, bilgilerinin alınarak güvenlik açığı olacağını ve sınır dışı edilebileceklerini düşünmeleri gerekçesi ile araştırmaya katılmamışlardır.

5. Türkmen işçilerin bazılarının ifadelerinin analize dahil edilmeyecek kadar kısa olması da sınırlılık oluşturmuştur.

\section{Verilerin Analizi}

Araştırmanın amacı doğrultusunda yapılan görüşme dökümleri ve gözlemler önce kâğıt üzerine, daha sonra da MAXQDA 2020 programina aktarılarak betimsel analizi yapılmıştır.

Araştırmaya dahil olan katılımcılar, iş deneyimlerini farklı meslek dallarında elde etmişlerdir. Araştırma kapsamında, katılımcıların göç evrelerindeki iş hayatları ve yaşam koşulları incelenmiş, Türkiye'deki iş deneyimleri ile ilgili olarak veriler elde edilmiştir. Katılımcıların, Türkiye'deki iş deneyimleri kapsamında, meslekler ve iş hayatı deneyimleri, çalışma hayatındaki sorunlar, çalışma hayatındaki memnuniyetleri ve memnuniyetsizlikleri ile ilgili tespitlerde bulunulmuştur.

Farklı kültürel yapıları ve yaşam biçimleri olan katılımcılar ile görüşmeler esnasında kişilerin duygu ve düşünceleri, duygusal 
durumlarına dayalı jest ve mimikleri ile ilgili çıkarımlarda bulunulmuştur. Araştırmada, katılımcılarının menşe ülkelerindeki yaşam koşulları ile hedef ülkeye geldikten sonraki sürece kadar olan deneyimleri ve tecrübeleri elde edilerek mevcut durumun analizi yapılmaya çalışılmıştır.

Özellikle MAXQDA programının kullanılması aşamasında çeşitli frekans grafiklerinden /tablolarından, kod-alt kod bölüm haritalarından, kod matrislerinden faydalanılmıştır. Söz konusu analiz edilecek belgelerde yer alan hususlar, tekrarlar, vurgular ya da araştırmacı tarafından not alınan davranış kalıpları, araştırmacının temel aldığ kuramsal çerçeve ve yaklaşımlar doğrultusunda değerlendirilerek kodlamaları yapılmıştır. Kodlamalar yapılırken alt kod durumunda bulunan önemli bir hususun sıklığının ve öneminin artmasına binaen, alt kodlar tema haline getirilmiş ve ayrı bir ana başlık altında incelenmiştir.

\section{Bulgular}

Demografik bulgular (2. Düzey başlık, 10,5 punto, bold, metin hemen başliyor)

Çalışmada Türkmen katılımcıların iş deneyimleri ile ilgili olarak görüşmelerden elde edilen verilerin analizi yapılmıştır. Türkmenlerin iş piyasasına erişimleri, iş deneyimleri, yaptıkları meslekler ve iş hayatları ile ilgili bulgular paylaşılırken çalışma hayatı dolayısı ile tecrübe ettikleri deneyimlerin olumlu ve olumsuz tarafları da görüşmelerindeki ibarelerden elde edilmiştir. Araştırmaya katılan Türkmenlerin tamamı erkek katılımcılardan oluşmaktadır. Araştırma kapsamında her ne kadar kadın Türkmen çalışanların olduğu katılımcılardan öğrenilse de araştırmaya katılım için gönüllü olmadıkları ya da kendilerine ulaşılamadıkları görülmüştür. Araştırmaya katılan katılımcıların yaşlarının 18 ile 30 yaşları arasında olduğu tespit edilmiştir. Türkmen katılımcıların yaş dağılımlarına bakıldığında en fazla yaş aralığının \%65 ile 18-23 yaş aralığı olduğu, diğer dağılımlarda da \%27,5 oranında 20-27 yaş, $\% 7,5$ oranında $28-30$ yaş olduğu anlaşılabilmektedir.

Meslekler ve iş hayatı ile ilgili bulgularda katılımcıların meslekleri, çalışma süreleri, iş bulma yöntemleri, iş bulma süreçlerindeki zorluklar, 
çalışmayı geciktiren faktörler, kazanç ve iş başlangıç zamanları ile ilgili verilere rastlanmıştır. Yapılan tespitlerde en fazla lokantada paketçilik, komi, berberde çıraklık ve fabrika işçisi mesleklerinin yoğunlukta olduğu görülmüştür.

İş bırakma nedenleri kapsamında elde edilen veriler ışığında, ücret azlığı, işten çıkarılma, çalışma şartlarının ağırlığı, sağlık nedenleri, kötü muamele, maaş alamama gibi nedenlerden dolayı Türkmenlerin işlerini bıraktıkları anlaşılmıştır. Katılımcıların söylemlerinde, çalıştıkları iş yerinden günlük yevmiye almalarına rağmen bu ücretin geçim koşullarına yetmediği, ücret azlığının işi bırakmaya yönlendirdiği, kazandıkları para ile birlikte yol ücreti giderlerinin fazlalaştığı ve iki vesait ile gidilen işleri tercih etmedikleri, standardın oldukça altında cüzi ücretlere çalışılması ve daha başka iyi bir iş bulma ihtiyacı hissetme durumları görülmüştür. Sosyal güvencesi olmayan işçilerin geçirdikleri kazalar sonucu herhangi adli ya da idari işleme maruz kalmak istemeyen işletmenin daha fazla kişiyi çalıştırmaması, iş ile ilgili teknik konulara hâkim olamama, iş yeri kurallarına uymama gibi durumlardan dolayı işten çıkarılma durumları yaşandığı anlaşılmıştır. Ayrıca çalışma şartlarının ağır olmasına karşın düşük ücretle çalıştırılmaları, geç saate kadar çalışmanın yorucu şartları içerdiği, iş koşullarının dayanılmaz olması gibi nedenlerden dolayı katılımcıların işlerini bırakmak zorunda kaldıkları görülmüştür. Psikolojik ve fiziksel sağlık sorunlar ve ağır iş koşullarının fiziksel tahribatının olmasının yanında işveren ve iş arkadaşlar tarafından ayrımcılığa maruz bırakılarak kötü muamele görmeleri iş bırakmanın diğer sebepleri olarak belirlenmiştir.

İş bulma yöntemleri ile ilgili olarak elde edilen bulgularda akraba yardımı, kendisinin iş bulması, arkadaş yardımı, zincirleme iş bulma, aileden birisinin iş bulması, sosyal ağların iş bulması gibi faktörlerin etkili olduğu anlaşılmaktadır.

Araştırmada çalışma sürelerine bakıldığında 3-6 ay ya da 1-3 ay arası çalışma süreleri göze çarpmaktadır. 18 ay ve üzerindeki çalışma zamanları, en az orana sahiptir. Bu doğrultuda Türkmen katılımcıların işlerde istikrarsız oldukları ve kısa süre içerisinde daha önceki bölümlerde belirtilen durumlardan dolayı işten ayrıldıkları görülmektedir. İşyeri sahipleri ile yapılan görüşmede göçmenlerin hane halkından 
çalışmayanların olduğu, bundan dolayı aile içinde nöbetleşe çalışma sistemi getirdiklerini belirtmişlerdir.

Aile üyelerinin çalışma durumlarına bakıldığında abi/kardeşlerin Türkiye'de de iş hayatlarını sürdürdükleri görülmektedir. Abi/kardeşlerin en fazla çalıştıkları meslek fabrika işçiliğidir. Çeşitli meslek gruplarında da çalışmayı sürdüren abi/kardeşler, hane halkının ihtiyaçlarını karşılamada önemli rol oynamaktadır. Katılımcıların mensubu olduğu ailenin reisleri olarak babalar, her ne kadar göç öncesi aile geçimini sağlamak için çalışsa da araştırmada yapılan tespitte $\% 66,7$ 'sinin Türkiye'ye geldiklerinde çalışmadığı belirtilmiştir. Babaların çalışmaması ile ilgili olarak sağlık sorunu yaşamalarının ve ülkelerindeki memurluk hizmetlerinin geçmişe dönük maaşlarının verilmesinin etkili olduğu görülmüştür.

İş bulma sürecini zorlaştıran faktörler ile ilgili yapılan incelemelerde dil bilmemekten kaynaklı iş bulma zorluğu, yabancı olmalarından kaynaklı dışlanma faktörü, yaşam alanını tanımama ve mesleki yetersizlik unsurlarının etkili olduğu görülmüştür. Katılımcıların özellikle ilk iş arayışlarında dil ve yer bilgisinin (adres bilgisi) olmamasından kaynaklı iş kabulü görmedikleri, katılımcıların kendilerine dil öğrenmeleri için zaman verilmesi gerektiğini düşündükleri, ilk iş deneyimlerinde adres bulmak için çeşitli stratejiler denedikleri, çevrelerinde dil bilmeyen arkadaşlarının iş hayatında ciddi sıkıntılar yaşadığını ve hepsinin bir alışma süreci yaşadıklarını, yabancı olmalarından kaynaklı olarak iş verenlerin ön yargılı oldukları, halkın Suriyelilere ön yargıları olması nedeniyle kendilerinin de Suriyeli sanmalarına istinaden Türkmen olduklarına ikna etme çabalarının olması, iş güçlerini ve iş ahlaklarını kanıtlamak için çeşitli kanıtlama yolları geliştirdikleri (örneğin bir iki gün ücretsiz çalışma vb.) görülmektedir.

Çalışma hayatındaki sosyal sorunlarla ilgili olarak görüşmeler sonucunda elde edilen verilere ilişkin ortaya çıkan sosyal sorunlar işsizlik, sosyal güvence eksikliği ve çocuk işçiliğidir. 


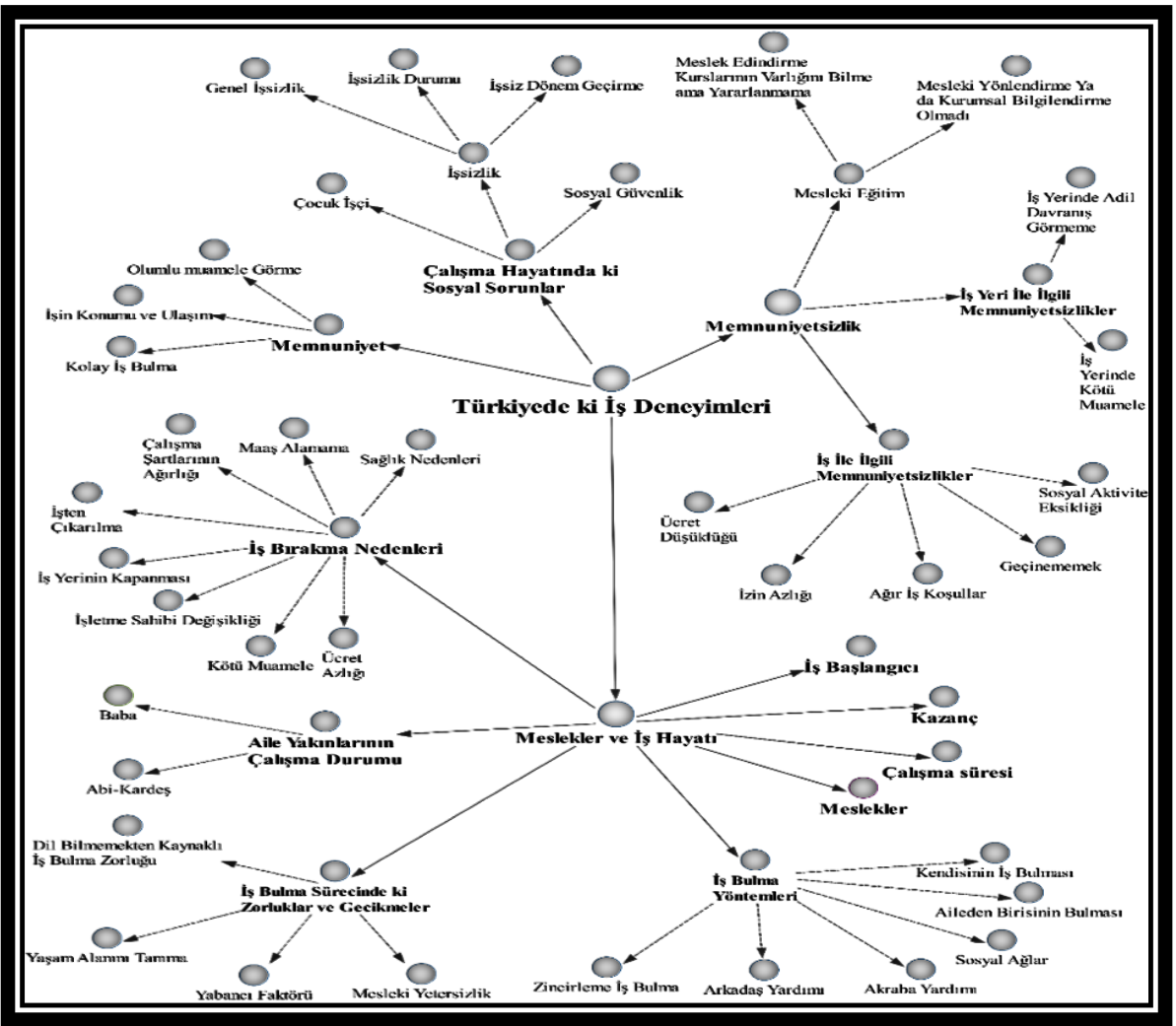

Şekil.1 Türkmenlerin Türkiye'deki İş Deneyimleri İle İlgili Olarak Oluşturulan Kod Hiyerarşisi Haritası

İşsizlik sorunu ile ilgili olarak katılımcılar kendilerinin işsiz kalma süreçleri, genel işsizlik durumlarını ve aile üyelerinin çeşitli şekillerde işsiz kalma tecrübelerini aktarmışlardır. Buna göre işin çeşidine göre sürekliliğin olmadığı, katılımcıların çevrelerinde halen iş arama sürecinde olan işsizlerin olduğu, işsizlerin iş bulmak için sosyal ağları kullandıkları ve onlara iş bulma durumunda kendilerine haber vermelerini ilettikleri, piyasada genel bir işsizliğin olmasından dolayı iş bulmakta zorlanıldığı, iş yerlerinin ancak sipariş üretmek için destek mahiyetinde işçi aldıklarını ancak siparişin ya da işin tamamlandıktan sonra tekrar çağırılıncaya ya da sipariş gelene kadar geçici işsizliğin olduğunu, genel işsizliğin onların iş bulmasını da etkilediği, eğitim hayatının kendi ülkesinde sürmesinden dolayı gidip gelmeler yaşayan katılımcıların sürekli iş yerine günlük ücret 
alacakları bir iş aramaları ancak bu türde işlerin bulunmadığı gibi konular tespit edilmiştir.

Katılımcıların tamamının sosyal güvence kapsamında olmadığ edilmiştir. Yapılan taramalarda sosyal güvenlik konusunda katılımcılara herhangi bir bilgilendirmenin yapılmadığı, yapılan bilgilendirmelerin yanlış olduğu ve bazı mecraların bu durumu istismar etmek için kullandığı bilgisine ulaşılmıştır. Katılımcılar, genel olarak tedbir amaçlı küçük yaşta işe başladıklarını belirtmeseler de araştırmacının sorularına verilen cevaplarda çocuk işçiliği sorunsalına ilişkin çıkarımlar elde edilmiştir.

İş hayatı ile ilgili memnuniyetsizlikler ile ilgili bulgular, iş yeri ile ilgili memnuniyetsizlikler ve iş ile ilgili memnuniyetsizlikler olarak ikiye ayrılmıştır. İş ile ilgili memnuniyetsizliklerin, ağır iş koşulları, adres öğrenmenin önemi, ücret düşüklüğü, izin azlığı, ekonomik sıkıntı yaşama, sosyal aktivite eksikliği, işsiz kalma korkusu, iş sürekliliğinin olmaması olduğu görülmüştür. Ağır iş koşulları kapsamında elde edilen verilerde, katılımcıların, çalışma kültürü bakımından Türk halkı ile aynı iş koşullarına (ağır iş yükü, uzun çalışma saatleri) alışık olmadıklarını, ağır işlerin kendileri tarafından da tercih edilmediğini, ağır iş koşullarının fiziki tahribat yarattığını, bazı iş kollarının şartlarının kalmaya ve yaşamaya elverişli olmadığını, çalışma saatlerinin kendi ülkelerine göre çok fazla olduğu görülmüştür. Ücret düşüklüğünden kaynaklanan memnuniyetsizliklerde, iş arayan yakınlarının ücret düşüklügünden dolayı iş bulamadıklarını, iş yeri kurallarına uymama durumunda iş veren tarafından ücretlerde kesintilere gidildiği, düşük ücretlerle Türkmenlerin çalıştırıldığı, yabancı olmalarından dolayı düşük ücret verildiğini düşündükleri görülmüştür. İzin azlığından kaynaklanan memnuniyetsizlikler ile ilgili olarak, yoğun çalışılmasına rağmen izinlerin kullandırılmadığı, hafta sonlarındaki izinlerin bile bazen kullanılamadığı, yabancı olmalarından dolayı izin konusunda çifte standart uygulandığı görülmektedir. Geçinme sıkıntısı ile ilgili olarak aynı iş gücü ile kendi ülkelerinde daha iyi ekonomik imkanlara sahip olunabileceği, ülkelerinde yaşadıkları yaşam şartlarının burayla aynı olmadığı, burada da yaşamın pahalı olduğu, şu anda işsizlikten dolayı geçim sıkıntısının olduğu ve çaresizlikler yaşandığı, evde çalışan aile bireylerinin olmasına rağmen geçimin sağlanamadığı görülmüştür. 
İşyeri ile ilgili memnuniyetsizliklerin iş yerinde kötü muamele ve iş yerinde adil davranış görmeme oluşturmaktadır. İşyerinde kötü muamele ile ilgili olarak katılımcıların söylemlerinde, işyeri sahiplerinin kızgın davrandıklarını, yanlış yapmaları durumunda çeşitli şekillerde cezalandırıldıkları (para kesimi, izin verilmemesi vb.), kendilerine küfürlü konuşmalar yapıldığı, iş yerinde sözlerin tutulmayarak hak edilen ücretin verilmediği, daha sonra paralarının verilmek istense dahi bu sözlerinin tutulmadığı, cep telefonlarını kullandıklarında sürekli azarlandığ1 konuları görülmüştür. Türkmenlerin, yabancı olarak algılandıklarından dolayı iş dağılımında adaletsizlikler olduğunu, kendileri ile birlikte çalışan yabancılarla da ayrım yaşandığı görülmüştür.

Yapılan görüşmelerde elde edilen bulgularda iş hayatının dil öğrenmeye etkisinin olduğu, Türkçe ve Türkmence dil yakınlığının dili öğrenmede dili öğrenmede etkili olduğu ve Irak'ta yapılan Türk radyo ve televizyonlarının yayınlarının büyük ölçüde Türkmenler için Türkçe'nin kullanımında temel olduğu görülmüştür. İş hayatının dil öğrenmeye etkisi ile ilgili olarak katılımcılar, çalışırken daha aktif dil öğrenme olduğunu, en başta hızlı konuşulmasına rağmen iş yerinde bu duruma da alıştıklarını, zamanla iş ile müşterilerle karşılıklı iletişim kurarak daha iyi öğrenme sürecinin olduğunu, yavaş ve aşamalı evrelerden geçerek dil öğrenmenin yanında okuma yazma gibi becerilerin de kazanıldığı, ülkelerinde Türklerle çalışanların Türkçe olarak daha avantajlı olarak buraya geldikleri görülmüştür. Araştırma süresinde katılımcıların en fazla kullandığı durumlardan birisi de Türkçe ve Türkmencenin yakınlığıdır. Daha önce de bahsedildiği gibi Türkmenler ile Türklerin soydaş olmaları nedeni ile dil benzerliklerinin olduğu bilinmektedir. Bundan dolayı katılımcılar genel olarak Türkçe öğrenme stratejilerinde bu yakınlığı avantaj olarak kullanmışlardır. Katılımcılar ülkelerinde faaliyet gösteren basın yayın organlarını takip ettiklerini ve bunların Türkçe dilini öğrenmelerinde katkılarının çok büyük boyutta olduğunu dile getirmişlerdir. Türkmenler ülkelerinde Türk Radyo ve Televizyonlarını izlemeleri yanında, özellikle Kemal Sunal filmlerinden etkilendiklerini ve yayınlanan diğer dizilerin de beğenilerek izlenildiğini belirtmişlerdir.

Çalışmanın başlığında da yer alan Sosyal Kabullenme teması ile ilgili olarak katılımcılardan alınan veriler doğrultusunda, olumlu kabullenme ile kabullenme sırasında yaşanan olumsuzluklar ile ilgili bilgilere 
ulaşılmıştır. Olumlu kabullenme ilgili olarak katılımcıların toplumsal kabullenme ile ilgili deneyimleri görülmüştür. Bu kapsamda olumlu kabullenme ile birlikte komşuluk ilişkilerinde ve Türk halkının verdiği destekten kaynaklanan olumlu ilişkilerin geliştiği söylenebilir. Kabullenmede olumsuz deneyimler ile ilgili olarak, ev kiralamada yaşanan sorunlar, apartmandaki komşuların şikayetleri, yabancı olarak görülmeleri nedeniyle halkın olumsuz davranışlarına maruz kalma ve ötekileştirmeler yaşandığı bilgisine ulaşılmıştır.

Olumlu kabullenme ile ilgili olarak katılımclar, sosyal kabullenmenin karşılıklı olarak gerçekleştiğini, diğer uyruklarla olan kabullenmelerde bazı sıkıntıların olduğunu, ilk gelişlerinde başta dil sorunu olmak üzere birçok sıkıntı yaşanmasına rağmen çevredekilerin desteği ile bunların üstesinden gelindiği, kabullenmenin olması bu ülkede yaşama için önemli bir kriter olduğu, Türk vatandaşlarının ve akrabalarının karşılıklı kabullenmede çok büyük etkilerinin olduğu, çalışma hayatında koşulların uygun olması haline herhangi bir kabullenme probleminin olmayacağı, her ne kadar kabullenme konusunda bazen sıkıntı çıkaranlar olsa da bu durumları anlayışla karşılayabildikleri, yaşam kurallarının öğrenilmesi ve uygulanması durumunda hiçbir zorluk çekilmeyeceği bilgisi elde edilmiştir.

Olumlu kabullenme durumları olduğu gibi çeşitli nedenlerden kaynaklı olumsuz durumların olduğunu da söylemek mümkündür. Sosyal kabullenmeyi zorlaştıran durumların katılımcılar tarafından ifade edildiği görülmüştür. Buna bağlı olarak ötekileştirme yapılması, halktan kötü muamele görülmesi bu olumsuzlukları bünyesinde barındırmaktadır. Ötekileştirme ile ilgili olarak, katılımcıların, yabancı olmalarından dolayı kabul görmelerinde çeşitli zorluklar olduğunu, bundan kaynaklı ötekileştirmenin iş yerinde de çifte standart olarak uygulandığı, ikametlerinde de yabancı olmalarından dolayı hiçbir şey yapmasalar da sıkıntılar yaşandığı tespit edilmiştir. Halktan kötü muamele görmek ile ilgili olarak katılımcilardan elde edilen veriler ışığında, günlük aktivitelerini yaparlarken yabancı olmalarından dolayı sosyal çevrede kabul görmedikleri, savaştan kaçıp geldikleri için halkın kendilerini suçlu gibi gördükleri, kendi durumlarını anlatmaya çalışsalar da Türk halkının empati kurarak bu durumun üstesinden gelemediği, çaresizliklerini anlatsalar da kendilerini kabul ettiremedikleri, sözel 
saldırıların yanında fiziki saldırılara da maruz kaldıkları, Suriyelilerle aynı kefeye kondukları ancak bunun tamamen yanlış olduğu görülmüştür.

Uyum teması katılımcıların genel yaşam koşullarına uyumları ile ilgili çeşitli kategorileri barındırmaktadır. Bu bölümde uyum ile ilgili yapılan araştırmalardan farklı olarak kimlik algısı, günlük hayat deneyimleri, temel hak ve yükümlülükler ile ilgili bilgi durumu ve uyum-dil ilişkisi ele alınmıştır.

Temel hak ve yükümlülükler ile ilgili olarak katılımcılarda araştırmacı tarafından bilgi ya da bilgilendirme eksikliği görülmüştür. Temel hak ve yükümlülükler ile ilgili olarak katılımcıların, geldiklerinde yaşlarının küçük olduğunu bazı hakları ve yükümlülükleri yeni yeni kendilerince keşfettiklerini, söz konusu hak ve yükümlülükler ile ilgili bilgi alınacak yerlerin bilinmediği, iş yerinde çalışırken sosyal güvence ya da sigorta ile ilgili olarak herhangi bir bilgilendirme yapılmadığı, başvurularda sadece kimlik çıartıldığı onun haricinde herhangi bir bilgilendirme yapılmadığı, çalışma izni ile ilgili olarak izlenilecek yolların nasıl olduğunu bilmediklerini belirtmişlerdir. Dil konusu her kategoride olduğu gibi uyum temasında da irdelenmiştir. Bu kapsamda katılımcıların uyum ve dil ilişkisi ile ilgili olarak, kökenlerinin Türklerle aynı yerden olduklarından dolayı Türkçe öğrenmeye özen gösterdikleri ve kolay alıştıkları, dil konusunda sıkıntı çekenlerin ciddi uyum sıkıntıları yaşadığı, iletişimde hala sorunlarının olduğu ve günlük hayattaki işlerini hallederken Türkçe bilen yakınlarından yararlandıkları, dil sorununu geldikleri ilk dönemde akrabalarının sayesinde daha kolay çözebildikleri, gençlerin dili öğrenmeye daha yatkın olduğu, yaşlıların ise hala dili bilmediği görülmüştür.

\section{Tartışma ve Sonuç}

$\mathrm{Bu}$ bölümde kitlesel göç, sosyal kabullenme ve uyum bağlaminda Türkmen işçilerin çalışma deneyimleri ile ilgili olarak Türkmenlerle yapılan görüşmelere ilişkin bulgular alan yazınındaki çalışmalar ekseninde tartışılmıştır.

Küreselleşme döneminde dünyada iş piyasalarına erişim, ekonomik unsurların en önemli noktasını oluşturmaktadır. Ekonomik sıkıntılar ve 
jeopolitik krizler yeterli iş imkanlarının azalmasına ve çeşitli ekonomik göç hareketlerinin de olmasına neden olmuştur.

Göçmenlerin başka bir ülkeye geldiklerinde yaşadıkları en büyük sıkıntılar arasında dil, uyum ve ekonomi konuları başı çekebilmektedir. Göç hareketleri incelendiğinde özellikle iş piyasasına erişimde, başka bir ülkede bulunan sosyal ağların etkili olduğunu söylemek mümkündür. $\mathrm{O}$ ülkenin kültürünü bilen ve iş piyasasına erişimi mümkün olan kişiler, yeni gelen göçmenlere köprü niteliği görebilmektedir.

Günümüzde devletler, kendi ekonomilerini güçlendirmek, sosyal ihtiyaçlarını karşılamak, insani yardım, tarihi bağlar, sınırlarını kontrol etmede yaşanan yetersizlikler gibi farklı nedenlerle isteyerek ve/veya istemeden göçmen kabul etmektedir. Uyum kavramı, toplumsal yapının görüşlerini yansıtan kamu politikaları aracılığı ile normatif olarak açıkça ifade edilmektedir (Şeker, 2015).

Sosyal izolasyon bazlı düşünüldügünde, kültürlerin çatışması ya da ülke vatandaşlarının göçmenlere külfet olarak bakması sonucu toplum içine almama gibi durumların yaşanabileceği düşünülebilir. Aslına bakılırsa sosyal izolasyon ve sosyal kabullenme kavramlarının birbirlerine bağlı olduğu da varsayılabilir. Ancak sosyal izolasyonda göçmenler ya da sığınmacılar, kabullenme aşamasına geçemedikleri için problemler yaşamakta ve yalnızlaştırılmaktadır. Bunun sonucunda da iş piyasasına erişim engellenebilmekte, sosyal destek ve ev geçindirme gibi sistemlerden yararlanmayabilmektedirler.

Sosyal kabullenme, bir olgunun ya da yaşama biçiminin, toplumun dinamiklerine uyum aşamasında, beraber yaşanılacak bireylerin farkındalık düzeylerinin arttırılarak, bireyin ya da topluluğun yaşamını sürdürmesi ve toplum tarafından herhangi bir rahatsızlık yaşanmaksızın hayati faaliyetlerine devam ettirilmesi olarak tanımlanabilir. Bu konu her ne kadar "uyum" kavramı ile özdeşleştirilmeye çalışılsa da bazı noktalarda farklılıklar görülebilmektedir. Uyumun, sosyal kabullenmenin tamamlanmasında bir araç ya da süreç olduğu düşünüldüğünde birbirine bağlı oldukları söylenebilir.

Göçmenler ve sığınmacılarda da toplumun bir onay süreci söz konusudur. Bu bağlamda yurtdışından gelen göçmenlerin toplumun değer yargılarına ve kültürlerine uyum sağlamaya çalıştı̆̆ 1 süreç çok önemlidir. Özellikle kitlesel göç ile ülkeye giriş yapan göçmenlerin 
uyumu daha büyük önem arz edebilmektedir. Kitlesel göçlerin toplumsal bir olay olarak algılanması ve gelen kitlenin görsel ve yazılı basın tarafından da takip edilmesi topumun bakış açısını da etkilemektedir. Görsel ve yazılı basında çıkan haberler toplumda ahlaki korkuya neden olabilmekte ve buna bağlı olarak çeşitli toplumsal tepkileri görmek mümkün olabilmektedir.

Karataş'ın (2016) yapmış olduğu çalışmada Suriyeliler ile ilgili basında çıkan haberler değerlendirilmiştir. Buna göre "Tepki" kavramı en fazla haberlerde yer alan olgu olurken, Suriyelilere yönelik saldırılar, yerel tepkiler, başkaldırılar, şiddet olayları, karşıt gösteriler, arabalara saldırı, slogan atma gibi olayların basında daha sık yer aldığ tespit edilmiştir.

Uyum sürecinin çok iyi yönetilmesi ile birlikte kurum ve kuruluşların alacağı tedbirlerde sosyal kabullenme için önem taşımaktadır. Sosyal kabullenme ile birlikte göçmenlerin ya da sı̆̆ınmacıların her türlü hizmete ve iş piyasasına daha kolay erişim sağlanabilecekleri düşünülebilir.

Göçmen işçilere düşük ücret uygulanmaktadır. Tüm dünya ülkelerinde yabancı işçiler aynı sorunla karşı karşıyadır. Bir göçmen işçi, ülke vatandaşından daha düşük ücretle çalıştırılmaktadır. Bu durum kayıt dışı çalışmanın bir sonucudur (Gemici, 2016). Araştırmada katılımcılar ücretlerin ilk geldiklerinde çok düşük olduğunu, daha sonrasında piyasanın ücret bakımından artış gösterdiğini dile getirmişlerdir. Ekonomik zorluk yaşayan katılımcıların ücret azlığından dolayı geçinemedikleri, bundan dolayı geçim sıkıntısı nedeniyle işlerini bırakarak daha iyi ücret veren iş yerlerine geçiş yaptıkları görülmüştür.

Suriyeli sı̆̆ınmacılar üzerinde yapılan bir araştırmada, Suriyeli mültecilerin sadece pazar günü çalışmadıkları varsayıldığında, haftada ortalama 74,5 saat çalıştıkları hesaplanmıştır. Fazladan çalışılan haftalık 29,4 saatin karşılığının hiçbir biçimde ödenmediği, ayrıca tehlikeli işlerde daha çok çalıştırılmaları ve günlük çalışma sürelerinin yerli işçilere göre daha uzun olması gibi nedenlerden dolayı göçmen iş̧̧ilerin iş kazalarına daha fazla maruz kaldığı, yaklaşık bir yıldır çalışmalarına rağmen, herhangi bir işyeri hekimliği ya da iş güvenliği hizmeti alamadıklarını ve işe giriş muayenelerinin yapılmadığı belirlenmiştir (Kaygısız, 2017). Bu bağlamda sığınmacıların ağır ve tehlikeli şartlarda çalıştıkları görülmektedir. Çalışmada Türkmen katılımcıların işyerindeki personelin ağır işlerde onları ileri sürdükleri, adres bulamama gibi durumlarda iş 
kaybı kaygısı yaşayarak çalıştıklarını, çalışma şartlarının ağır olmasına karşın düşük ücretle çalıştırılmaları, geç saate kadar çalışmanın yorucu şartları içerdiği, iş koşullarının dayanılmaz olması gibi nedenlerden dolayı iş bıraktıkları görülmüştür.

Kötü muamele nedeniyle iş bırakma ile ilgili olarak katılımcılar, işyeri sahiplerinin sözlü ve fiziki saldırılarının olduğu, iş ortamında çalışan diğer çalışanların da onlara kötü davranması, çeşitli sebeplerden dolayı patronları ile anlaşmazlıklar yaşandığı belirtmişlerdir. Yapılan bir araştırmada Azerbaycanlı kadınların emek piyasalarındaki sosyal dışlanması, güvencesiz ve düşük ücretli işlerde çalışmalarından ve de bunun ötesinde ülkede izinsiz kalan kaçak göçmen olarak eğreti konumlarından kaynaklandığı, aynı işi yapan yerli çalışanların güvencesizliğinden daha farklı boyutta olan güvencesizliklerinden dolayı, işyerlerinde marjinalize edilmekte oldukları ve sıklıkla çalıştıkları işverenlerinin ve çalışma arkadaşlarının kötü muamele ve aşağılamasına maruz kaldıkları belirlenmiştir (Dedeoğlu, 2011). Sığınmacıların öteki olarak görülmesinden dolayı çalışma ortamında taciz ve şiddete maruz kaldıkları (Aslan ve Güngör, 2019), sadece iş yeri sahibi değil, diğer çalışanlar tarafından da zor durumda bırakılmaları nedeniyle işi bıraktıkları görülmüştür.

Araştırmacı tarafından, iş bulma yöntemlerinin, sı̆̆ınmacıların iş deneyimlerinde açısından önemli olduğu değerlendirilmiştir. Bu kapsamda katılımcıların anlatımları ile iş bulma stratejilerinin genel olarak akraba yardımı, kendisinin iş bulması, arkadaş yardımı, zincirleme iş bulma, aileden birisinin iş bulması ve sosyal ağların yardımının olduğu anlaşılmaktadır. Kone, Ruiz ve Silva tarafından 2019 yılında hazırlanan "Sığınmacılar ve Birleşik Krallık işgücü Raporu'na göre yapılan analizlerde işsiz sığınmacıların iş ararken en çok kullandıkları ve güvendikleri faktör toplumsal kurum ve kuruluşlardır. Yine bu analize göre beş çeşit iş bulma yönteminden bahsedilmektedir. Bunlar: Resmi Kurum ve Kuruluşlar, Özel Kurumlar, Reklamlar, İşverenlerle Direk Görüşme ve Sosyal Ağlardır.

Akrabaların, arkadaşların, aile bireylerinin ve tanıdıkları iş çevresinin iş buldukları zaman hemen kendilerini arayarak işlere yerleştirdiklerini belirten katılımcılar, sosyal ağların çalıştıkları yerde eleman açığı olması ve referans olmaları durumunda işe çağırıldıkları, iş şartlarını katılımcıya 
sosyal ağdaki insanların aktardığı, sosyal ağların başka bir iş bulana kadar geçimlerini sağlayacak işleri de ayarladıkları, genel olarak kendilerinin çalıştıkları yere akrabalarını da yerleştirdikleri görülmektedir. Akrabalık ve aile bağları, kültürel ve ekonomik sermayeyi sağlamanın yanında barınma, iş bulma ve bürokratik işlemlerin halledilmesini sağlama gibi konularda destek sağlamaktadır (Demirbaş ve Akyiğit, 2018).

İş bulma sürecindeki zorluklar, katılımclar tarafından dil bilmemekten kaynaklı iş bulma zorluğu, yabancı olmalarından dolayı dışlanma, yaşam alanını tanımama ve mesleki yetersizlik olarak belirtmişlerdir. Londra'da yapılan bir araştırmada 22 sığınmacı ile görüşülmüş ve iş bulmadaki zorlukların kişisel, sosyal ve ekonomik boyutta farklılaştığı, özellikle iş bulmada kişisel zorlukların dil sorunları ile kesiştiği, bir çok sığınmacının dil bilmemesinden dolayı kendilerini dezavantajlı hissettikleri ve bu durumun iş bulmada ciddi zorluklar yaratacağını tahmin ettikleri, mesleki yeterliliklerinin ve uygunluklarının olmamasının da iş bulmada engel olacağı, bazı sığınmacıların dil becerilerini iş bulmak için geliştirmede yararlı olacağını düşünmelerine rağmen, bazılarının da dil becerilerinin olmamasının istihdama engel olmayacağını ancak yabancılara olan önyargının bunda daha etkili olduğunu düşündükleri sonuçlarına ulaşmışlardır (Archer, Hollingworth vd., 2005).

İş piyasasına erişim her ne kadar ekonomik olarak sığınmacıları rahatlatsa da beraberinde sosyal sorunları da barındırmaktadır. İşsizlik, sosyal güvence eksikliği ve çocuk işçiliği katılımcıların ifadelerinden elde edilen sosyal sorunlar olarak araştırmada yer almıştır. Burada çocuk işçiliği ile ilgili olarak katılımcılarda fazla ifadeler bulunmasa da araştırmacı tarafından çıarılan geliş zamanı-işe başlama zamanı-yaş kod matrisinde Türkmenlerin çoğunun iş başlangıçlarını çocuk işçi olarak yaptı̆̆ 1 tespit edilmiştir. Suriyeli sığınmacıların göç hareketinden sonra, işsizlik oranlarının arttığı, işte çalışma süresinin azaldığ sürelerinin arttığ tespit edilmiştir (Akcan, 2018).

Çocuk işçiliği konusu sadece göçmenler kapsamında değil, her boyutta günümüzde en önemli sosyal problemlerden biridir. Bu nedenle araştırmada çocuk iş̧̧iliği konusuna eğilmenin ve tartışılmasının yararlı olacağ1 değerlendirilmiştir. Küresel bazda bakıldığında dünyada 31 milyon çocuk sığınmacının olduğu tahmin edilmektedir (World 
Migration Report, İOM, 2020). Gelişmekte olan ülkelerde nüfusun hızla artması, düzensiz şehirleşme, gelir dağılımındaki adaletsizlik, işsizlik gibi sebeplerle çocuk emeğini kullanma büyük oranda ortaya çımıştır. Maddi açıdan yeterli düzeyde bir gelire sahip olmayan sı̆̆ınmacı ailelerin çocukları aile bütçesine katkıda bulunmak için kimi zaman ebeveynlerinin, kimi zaman kendi istekleriyle çalışmaktadırlar (Harunoğulları, 2016). BMMYK'nin Suriyeli Çocuk İşçiler ile ilgili olarak hazırlamış olduğu raporda çeşitli ülkelerde çocuk işçi vakasına rastlandığı, sığınmacı çocukların çeşitli ekonomik sektörlerde, mesleklerde ve faaliyetlerde bulunduğu tespit edilmiştir. Aynı raporda Türkiye'de sığınmacı çocuk işçilerin, tekstil, ayakkabı yapımı, oto mekanik, fırıncılık, sokak işleri ve tarımcılık gibi küçük ve orta ölçekli işletmelerde çalıştıkları yer almakla birlikte (BMMYK, 2017) Türkiye'de özellikle Suriyelilerin yoğun yaşadığı illerde çocuk işçiliğinin arttığ1 ve araştırıldığı gözlenmiştir (Bahadır ve Demiral, 2019).

Sosyal risklerle ve tehlikelerle karşılaşan her bireye sosyal koruma sağlamayı amaç edinen sosyal güvenlik hakkı kamu hak ve özgürlüklerinin başında gelmektedir (Ermumcu, 2013). Araştırma kapsamında katılımcıların tamamının sosyal güvencesinin olmadı̆̆ı anlaşılmıştır. Sosyal Güvenlik Kurumu verilerine göre Türkiye'de 2018 yılında \%33,42 oranında kayıt dışı istihdam bulunmaktadır (Sosyal Güvenli Kurumu Resmi Web Sitesi, Erişim: 17.02.2020). Kayıt dışı istihdam oranının da yüksek olduğu göz önüne alındığında, sosyal güvencenin de buna paralel olarak olmadığı, Türkmenlerin Genel Sağlık Sigortasına tabii oldukları görülmüştür. Kayıtlı işçi olma konusunda sığınmaciların, iş sahiplerinden resmi prosedürleri talep etmesi halinde kovulabilecekleri ihtimalinin olması, onları kayıtlı işçi yapmaktan uzak tutmaktadır (Diker ve İçduygu, 2017).

Katılımcılar tarafından memnuniyetsizlikler, iş ile ilgili memnuniyetsizlikler, mesleki eğitim ile ilgili bilgilendirme memnuniyetsizliği, işyeri ile ilgili memnuniyetsizlikler olarak ifade edilmiştir. Burada iş ve işyeri memnuniyetsizliklerini ayırt etmekte fayda vardır. Genel olarak bakıldığında memnuniyetsizlikler ile iş bırakma nedenlerinin örtüştüğü görülebilir. Buradaki fark, memnuniyetsizliğe rağmen iş hayatının devam etmesidir. Dünya Çalışma Örgütü (ILO) özellikle zorunlu göç ile gelen sığınmacıların iş piyasasındaki 
memnuniyetsizlikleri ile ilgili olarak on bir gösterge sıralamıştır. Bunlar: güvenlik açığını kötüye kullanma ve istismar etme, çalışanları aldatma, kişilerin hareketlerinin kısıtlanması, dışlanma, fiziksel ve cinsel şiddet, korkutma ve tehditler, kimlik belgelerinin saklanması, ücret kesintisi, kötü muamele, yaşam koşullarının zorluğu ve fazla çalışma (Dwyer, Hodkinson, Lewis ve Waite, 2016). İş ile ilgili memnuniyetsizlikler ağır iş koşulları, adres öğrenmenin önemi, ücret düşüklüğü, izin azlığ1, geçinememe, sosyal aktivite eksikliği, işsiz kalma korkusu, iş sürekliliğinin olmaması olarak belirlenmiştir.

Katılımcıların ifadeleri doğrultusunda işyeri ile ilgili memnuniyetsizlikler ile ilgili olarak kötü muamele ve adil davranış görmeme hususlarına değinilmiştir. Yapılan araştırmalarda iş yerinde kötü muamele görmek dile getirilen sorunlardan biridir (Güngör ve Aslan, 2019). Amerika'da yapılan bir araştırmada somut iş pozisyonlarında yabancıların değerlendirilmemesinden kaynaklanan ayrımclığın beraberinde çeşitli sözlü tacizleri de beraberinde getirdiği, ancak bunların görünür göstergelerinin olmamasından dolayı çevre tarafından anlaşılmadığı ve sadece yabancılar tarafından algılandığ değerlendirilmiştir (Mong ve Roscigno, 2009). İş yerinde adil davranış görmeme tutumunun sığınmacılara yapılan ayrımcılık dolayısı ile adil iş dağıtımının olmamasından kaynaklandığı görülmüştür. Toplumdan algılanan dışlanma, reddedilme veya ayrımcılık arttıkça göçmenlerin bireysel hareketlilik ile üst gruba dâhil olma beklentisi azalmaktadır (Taşdemir, 2017).

Sosyal kabullenme ya da diğer deyimiyle toplumsal kabullenme yaşamın her alanında görülebilen toplum hareketleridir. Göç unsurunda iki yönlü durum söz konusudur. Bunlar gelinen ülkenin vatandaşlarının kabulü ile yeni gelenlerin kabul etme mekanizmalarıdır. Kültürleşme, kültür etkileşimi sonucunda farklı boyutlarda var olan davranış kalıpları, gelenekler, görenekler, toplum kuralları, düzen sağlayıcı kanunların kabulü belirli bir oranda kabullenmeyi gerektirmektedir. Belirli görüşlerin, önlemlerin, öneri ve kararların, toplumsal gruplar tarafından onay alması şeklinde tanımlanan toplumsal kabul kavramının, bazı araştırmalarda meşruiyet kavramı ile de yakın bir anlama sahip olduğunun vurgulandığını belirtmek mümkündür (Sezgin ve Yolcu, 2016). İnsanlar grup içinde doğarlar ve toplumsal niteliklerini gruplarda 
kazanırlar. Bu gruplar aracılığıyla toplumda geçerli olan bilgiler, değerler bireye aktarılır (Karslı, 2013). Ancak çeşitli sebeplerden dolayı yerinden edilen ya da göç etmek zorunda kalan kişiler ile ilgili olarak toplumsal kabulün sağlanamaması beraberinde sosyal mesafeyi oluşturabilmektedir. Göç eden kişiler ile yeni yaşamlarını sürdürdükleri çevre arasında değişimlerin olduğu, bu değişimlerin sosyo-kültürel değişimlere neden olduğu, kendilerininde sosyo-psikolojik yönden değişebildikleri söylenebilir (Yardım, 2017). Araştırmada katılımcılar sosyal kabullenme ile ilgili olarak kabullenme ile kabullenme sırasında yaşanan olumsuzluklar ile ilgili deneyimler görülmüştür.

Uyum konusu özellikle yazınsal alanda sığınmacılar ile ilgili en çok ele alınan ve araştırılan faktördür. Araştırmacı, çalışması sırasında göç öncesi çalışmalardan çok göç sonrası yaşanan durumların ele alındığını ve uyumun her seferinde değişik açılardan ele alındığını görmüştür. Uyum süreci, sağlık durumu, iletişim yeterlilikleri, farkındalık, kabul duygusu, kültürel davranış becerileri, ekonomik yetersizlikler vb. olarak ifade edilen çok boyutlu bir yapıdır (Şeker, 2015).

\section{Sonuç ve Öneriler}

Bu araştırmada, Irak'tan gelen Türkmenlerin çalışma deneyimleri ile ilgili olarak tecrübeleri, çalışma hayatı ile ilgili olarak yaşadıkları olumlu ve olumsuz durumlar, çalışma hayatının onların görüşleri çerçevesinde uyum ve sosyal kabullenme olgularını nasıl etkilediği anlaşılmaya çalışılmıştır. Bu kapsamda araştırmada elde edilen önemli sonuçlar aşağıda yer verilmiştir.

Ekonomik ve sosyal zorluklar, göç sonrası dönemin bir sonucudur. Daha önceki bölümlerde tahmin edilmeyen para kayıplarının olmasının göç sonrası dönemde yeni hayat kurmada olumsuz etki yaratabileceği konusuna değinilmiştir. Türkmenlerin de yaşanan ekonomik zorluklara istinaden kirasının ucuz olduğunu öğrendikleri yerleşim birimlerinde yaşamlarını sürdürdükleri anlaşılmıştır.

Göç sonrası dönemde ülkeye yeni gelenlerin uyumunun sağlanması ve gerekli yaşam koşullarının oluşturulması en önemli faktörlerdir. Bundan dolayı: 
- Külfet paylaşımı (küresel olarak göçmenlerin sorumluluğunu alma) programlarının diğer ülkelerle eşgüdümlü olarak yürütülmesi gerekmektedir. Bundan dolayı gerek sığınmacılara sağlanacak hizmetler gerekse de üçüncü ülkelere çıkış programlarında ülkelerdeki kotaları arttıracak girişimlerin yapılması gerekmektedir.

- Gelen öncü kişiler ile yapılacak olan kayıt işlemlerinde doğru yönlendirilmeleri için gerekli ön bilgi ve mevzuat bilgilendirme dokümanlarının hazırlanarak kendi dillerinde kayıt esnasında kendilerine verilmesi gerekmektedir. Öncü kişilerin kuralları ve hakları doğru bilmesi, sonrasında gelecek aile üyelerinin var olan hizmetlere ve haklara ulaşımlarında büyük önem taşımaktadır.

- Bir diğer ele alınması gereken nokta da sığınmacıların yerleşim alanlarıdır. Öncelikli olarak sığınmacı nüfusunun hangi bölge olursa olsun yerleşim alanlarının haritalandırmasının yapılması gerekmektedir. Bundan dolayı söz konusu nüfus dağılımının bölgedeki ilçe birimlerine göre tespit edilmesi ve hizmetlerin bu haritalandırmaya göre yaygınlaştırılması gerekmektedir.

\section{Türkiye'deki İş Deneyimleri ile İlgili Sonuçlar}

Göç sonrası hedef ülkeye gelen sığınmacılar için en önemli engellerin başında geçimlerini sağlayacak iş kolunu bulmaları ve iş piyasasında erişimi sağlamalarıdır. Gelen sığınmacılar öncelikle temel insani ihtiyaç olarak barınma sorununu hallettikten sonra kazanç elde etme yolları aramaktadırlar. Sosyal ağların ya da diğer faktörlerin yardımı ile iş piyasasına giren göçmenlerin, iş hayatında karşılaşabilecekleri durumları bilmeleri daha iyi bir uyum sürecini beraberinde getirebilir.

Türkmenlerin Türkiye'deki iş deneyimleri ile ilgili olarak temel çıktılar iş piyasasına erişimleri, iş deneyimleri, yaptıkları meslekler, iş hayatlarında yaşadıkları tecrübeler ve bu deneyimlerinin olumlu ve olumsuz taraflarıdır. Daha önce de değinildiği gibi Türkmenlerin çoğunun ilk iş deneyimi Türkiye'de gerçekleşmiştir. Meslek dallarına bakıldığında genel olarak eğitim gerektirmeyen ya da iş içerisinde öğrenilebilen işlerin seçildiği görülmektedir. İş dallarında genellikle yardımcı konumda çalışan Türkmenlerin özellikle paket taşıma 
servislerini tercih ettikleri görülmektedir. Göç öncesi ve göç sonrasi meslek eşleştirme kriterlerine bakıldığında yok denecek kadar az kişinin menşe ülkesindeki işleri Türkiye'de yaptığı görülmektedir. Onun dışındaki bütün meslekler katılımcılar tarafından ilk defa yapılan ve daha önce ülkelerinde görmedikleri mesleklerden oluşmaktadır. Genel olarak bakıldığında uzman kurum ya da kuruluşlarca mesleki yönlendirme ile ilgili olarak herhangi bir ön değerlendirme ya da yönlendirme yapılmadığg görülmektedir.

Sürdürülebilir bir çalışma hayatının olması, aile ekonomisinde istikrarı sağlamaktadır. Ancak Türkmenlerin çeşitli nedenlerden dolayı işleri bıraktığı görülebilmektedir. Sığınmacıların küresel anlamda iş hayatı ile ilgili sorunu ücret azlığı ya da ücret dağılımının adil olmamasıdır. Ücret azlığındaki en önemli neden kayıt dışı çalışmadır. İşverenlerin maliyetleri düşürmek istemesi, yabancı işçi çalıştırma prosedürlerinin tam olarak bilinmemesi ve yabancı işçilerin kayıtlı ve sigortalı çalışması ile ilgili olarak mesleki eğitim programları kapsamındaki teşviklerden haberdar olmamalarından dolayı adil ücret sorunsalı yaşanabilmektedir. Ücret azlığ1 ve düşük kazançlar düşünüldüğünde, Türkmenlerin standart bir ücret almadığı görülmektedir. Genellikle çalıştıkları gün başı para alan Türkmenlerin, kimi zaman bahşiş gibi yevmiye tarzına tabii olmaları nedeniyle günlük kazançlarının tam olarak belli olmadığı sonucuna ulaşılmıştır. Ücret azlığına etki eden bazı etmenler de araştırmanın çıktıları arasında yer almıştır. İş yeri sahiplerinin standart ücret tarifesi uygulamamasına bağlı olarak ücret belirsizliğinin olması, özellikle düşük ücretlerle çalışanların birden fazla araç ile ulaşımlarını sağlamaları, çalışma koşullarının ağır olması ve çalışma saatlerinin düzensiz ve fazla olması dolayısı ile Türkmenlerin işleri bıraktıkları görülmüştür. Ayrıca ağır iş koşulları altında çalışan Türkmenlere iş sağlığı ya da güvenliği ile ilgili olarak herhangi bir prosedür uygulanmamıştır.

İşten çıkarılmaların Türkmenler tarafından sıklıkla yaşanan bir durum olduğu söylenebilir. İşverenlerin işe alma politikalarında sürekliliği değil de geçici ihtiyacı görme süresinin önemli olması sebebi ile işin bitiminde işten çıkarılmaların ve yeni bir sipariş ya da iş gelene kadar geçici işsizliklerin görüldüğü söylenebilir. Ayrıca iş verenlerin herhangi bir iş kazası sonucunda meydana gelebilecek yaralanmalardan dolayı muhtemel adli ve idari yaptırımlardan çekinmeleri nedeniyle işten 
çıkarmaların yapıldığı bu çalışmanın başka bir sonucudur. Bununla birlikte iş ortamında yapılan kötü muamele, işverenin, iş yerini çeşitli nedenlerden dolayı devretmesi ve daha da önemlisi Türkmenlerin emeği olan çalışma ücretlerinin ödenmesinde gecikme yapılması ya da ödenmemesi işi bırakma sebeplerinin çıktıları arasında yer almaktadır.

$\mathrm{Bu}$ araştırmanın iş deneyimleri ile ilgili olarak elde edilen en önemli çıktılarından birisi de Türkmenlerin iş bulma yöntemleridir. Yurt dişında sığınmacıların iş bulma ile ilgili en çok tercih ettikleri strateji ülkede hizmet veren iş bulma kurumlarıdır. Türkiye'de böyle bir kurumun olup olmadığını bilmeyen yabancıların iş bulma stratejileri akrabalar, aile üyeleri, kendi çabaları ile iş bulma, çevrelerinin ve sosyal ağlarının yardımı gibi stratejiler üzerine kuruludur. Genellikle, katılımcıların, akrabalarının ya da sosyal ağlarının iş ortamında bulunmaları ve eleman açı̆̆ı bilgisine ulaşmalarının ardından, yakınlarını boş olan iş pozisyonlara yerleştirdikleri bilgisine ulaşılmıştır. Burada Türkçe bilgisinin önemli olduğu değerlendirilmektedir. Keza dil bilgisi olmayan Türkmenlerin piyasada çok ciddi iletişim sıkıntıları çektikleri anlaşılmıştır.

Araştırmanın bir diğer önemli sonucu da iş sürekliliğinin olmamasıdır. Türkmenler, çoğu çalıştıkları işte kalıcı olmamışlardır. Bu durumun sebebi, sayılan iş bırakma nedenlerinin yanında hane halkındaki genç nüfusun fazla olmasından dolayı nöbetleşe çalışma sistemlerinin olmasıdır. Çalışma kültürünün, özellikle Türkmen gençler arasında, pek yaygın olduğu gözlemlenmemiştir. Bir süre sonra çalışma hayatından bıkan kişi eve gelir getirmesi açısından çalışma nöbetini bir diğer aile üyesine devredebilmektedir. Bunu yaparken de genel olarak kendi çalıştıkları işten ayrılırken nöbetçi çalışacak aile üyesini aynı iş yerinde istihdam edilmesini sağlamaktadırlar. Araştırmanın bir diğer dikkat çekici sonucu da Türkmenlerin işe başlangıç zamanlarıdır. Türkmenlerin çoğu, ülkeye geldikten sonraki 1-3 ay içerisinde iş piyasasına erişimlerini gerçekleştirmişlerdir. Bunun sebebi Türkmenlerin ekonomik olarak zorda olmaları ve hayat kurgularını hızlı şekilde yapmak istemeleridir. Bu açıdan bakıldığında sığınmacıların kısa süre içerisinde gelir getirici iş bulma eylemlerinin olduğunu söylemek doğru olur.

Aile üyelerinin çalışma durumları ve meslekleri de bu çalışmanın sonunda elde edilen çıktılardandır. Türkmenlerin babalarının iş hayatına 
çoğunlukla dahil olmadığı görülmektedir. Kardeş ya da abiler çalışma hayatlarını sürdürmektedirler. Babaların sağlık sorunlarının olması ya da Türkçe dil bilgisine hâkim olmamaları Türkiye'de iş bulma faktörünü etkilemektedir. Ayrıca geldikleri ülkede yaşam şartlarının normale dönmesi için çalışmaların olduğu, bundan dolayı da orada devlet memurluğu yapmış olan babaların birikmiş maaşlarını da aldıkları ve aile geçimine bu şekilde katkı verdiği bilgisine ulaşılmıştır.

Araştırmanın sonuçlarından biri olarak Türkmenlerin iş bulmada en çok zorlandıkları unsurların, dil bilmemekten kaynaklı iş bulma zorluğu, yabancı olma faktörü, yaşam alanını tanımama ve mesleki yetersizlik olduğu anlaşılmıştır. İş piyasası ile ilgili en büyük sorun dil sorunudur. Dil bilmeden iş arama noktasında sıkıntı yaşayan Türkmenlerin, iş yerinde de dil bilmemekten dolayı sıkıntı çektikleri anlaşılmıştır. Dil sorunu ile ilgili olarak hem Türkmenler hem de iş yeri sahipleri iletişim konusunda sıkıntılar yaşamaktadırlar. "Mesleki yetersizlikler" de, işyeri sahiplerinin işe almada en büyük kriteri olarak görülmektedir. Bu noktada dil eğitimleri ve mesleki eğitim ile ilgili programların varlığından ya da teşviklerinden hem işverenlerin hem de Türkmenlerin bilgilendirmedikleri anlaşılmıştır.

Bir sosyal sorunun çözümü bazen başka sosyal sorunların çıkmasına neden olabilmektedir. Ekonomik sorunların çözülmesi için iş hayatına dahil olunması yoksulluk gibi bir sosyal sorunu çözerken beraberinde sosyal güvence eksikliği ve çocuk işçiliği gibi sosyal sorunları getirmektedir. Türkmenlerin birçoğunun 18 yaşının altında işe başladığ 1 düşünüldüğünde çocuk işçiliği riskinin büyük olduğu görülmektedir. Aynı zamanda hangi uyruktan olursa olsun sığınmacıların iş piyasasına dahil olması, işsizlik oranlarının artmasına neden olmaktadır. İş sürekliliğinin olmaması sürekli ya da geçici işsizlik olmasına neden olmaktadır. Geçici işsizliğin olması da ailelerin kazanç istikrarlarının belli olmamasına ve hane halkı geçim oranlarının değişmesine neden olmaktadır. Türkmenlerin işlerde sosyal güvenceleri olmadan çalışmaları, ağır işlerde çalıştıklarından dolayı risk altında olmaları büyük bir sosyal sorundur.

Kolay iş bulabildiğini ifade eden Türkmenler, işlerinin konumuna ve ulaşılabilirliğine büyük önem vermektedirler. Ayrıca Türkmenler, Türk vatandaşlarının tercih etmediği iş kollarını keşfederek genel olarak bu 
meslekleri tercih ettiklerini belirtmişlerdir. $\mathrm{Bu}$ durumda Türk vatandaşlarının iş beğenmemelerinin ya da beceri uyumsuzluklarının, iş bulamama faktörlerine etkisinin olduğu görülmekte olup bu durumun işsizlik sorununa doğrudan etkisinin olduğu söylenebilir.

İş hayatı ile ilgili araştırma sonucunda elde edilen çıtılar meslek ile ilgili memnuniyetsizlikler, iş ortamından kaynaklanan memnuniyetsizlikler, mesleki eğitim ve bilgilendirme eksikliği olarak değerlendirilmiştir. Bundan dolayı Türkmenler meslek, iş alanı ve mesleki yetersizlikten dolayı memnuniyetsizlik duymaktadırlar. $\mathrm{Bu}$ olumsuzluklara bakıldığında aynı zamanda iş bırakma nedenleri ile örtüştüğü de görülebilmektedir. Ancak bazı durumlarda her ne kadar olumsuz koşullarda çalışılırsa çalışılsın ekonomik sıkıntıda olan Türkmenlerin çalışmaya devam etme mecburiyetinde oldukları anlaşılmıştır. İş ile ilgili memnuniyetsizlikler bu araştırmanın sonucuna göre, ağır iş koşullarının olması, adres öğrenememenin getirdiği kaygılar, ücret düşüklüğü, izin azlığı, geçinememe, sosyal aktivite eksikliği, işsiz kalma korkusu ve iş sürekliliğinin olmamasıdır.

İşyeri ile ilgili memnuniyetsizlik çıktıları kötü muamele ve adil davranış görmeme hususlarıdır. Türkmenler, işyeri sahiplerinin ve işyerinde çalışan kişilerin sözlü ve bazen fiziksel muamelelerine maruz kalmışlardır. Aynı zamanda hata yaptıklarında maaşları kesilmiş ve izinleri iptal edilmiştir. Türkmenlerin teknoloji bağımlılıklarının olması (cep telefonu vb.), işyerinde özellikle bu durumun antipati kazanmasına neden olmuş ve gereksiz kullanımlardan dolayı işyeri ile ilişkileri sıkıntıya girmiştir. Özellikle yabancı olmalarından dolayı ayrımcılık yaşadığını düşünen Türkmenlere genel olarak zor işler verilmiş ve işyerindeki çalışanlar ile çifte standartlar uygulanmıştır.

\section{Türkiye'deki İş Deneyimlerine İlişkin Öneriler}

Ülkelerinde yaşanan iç karışıklıklar ve çatışmalar dolayısı ile kitlesel olarak göç eden sığınmacıların, küresel bazda sosyal soruna dönüştükleri, gittikleri hedef ülkelerde ekonomik ve sosyo-kültürel etkiler yaptıkları görülebilmektedir. Bu etkilerin etkisinin azaltılması için sığınmacıların gelecekteki uyumlarının sağlanması ve buna bağlı olarak sığınmacı nüfusunun kapsamlı ve sürekli olarak değerlendirmesinin yapılması 
gerekmektedir. Özellikle iş piyasası ile ilgili olarak kontrollü ve sistematik çözümlemelerin yapılması gerekmektedir. Bu kapsamda;

- Sığınmacıların iş piyasası ile ilgili olarak olumlu sonuçlar alınması ve takip çalışmalarının yapılması etkili göç yönetimini gerektirmektedir. Bu bağlamda kayıt alma işlemlerinin etkin ve verimli yürütülmesi gerekmektedir.

- Sürdürülebilir iş olanaklarının sağlanması ve istihdam piyasalarının düzenlenmesi büyük önem arz etmektedir. Daha önce de belirtildiği gibi sığınmacıların hedef ülkeye gelmelerinden kısa bir süre sonra iş piyasasına erişim talepleri olmakta ve iş bulma ile iş sürdürülebilirliği kapsaminda problemlerle karşılaşılabilmektedir. Bu kapsamda kişisel ve çevresel şartların etkileri görülebilmektedir.

- Bazı durumlarda sığınmacılara statü verilmemesinden dolayı iş piyasasına erişimleri noktasında problemlerin yaşandığı görülebilmektedir. Bundan dolayı bazı ülkelerde yüksek başvuru sayılarının olması sebebi ile alternatif çalışma düzenlemeleri yapılabilmektedir. Genel değerlendirmelerin yapılarak çalışma hayatına katılım ve kayıtlı iş piyasasının oluşumu için bu tip düzenlemelerin yapılması gerekmektedir.

- Sığınmacılar için iş bulma destek birimlerinin profesyonel olarak yürütülmesi için kurumsal bazda yeni bir birim kurulması gerekmektedir. Kurumda kariyer uzmanlarının yanında psikososyal destek elemanlarının da bulunarak iş bulma, iş deneyimleri ve iş uyumu ile ilgili olarak psiko-sosyal destek vermeleri gerekmektedir. Aynı modelin beceri uyumsuzluğu olan Türk vatandaşları içinde kurulması ve mesleki yönlendirme yapılması mesleklere erişilebilirlik açısından önemlidir.

- Eğitim, yetenekler ve mesleki yeterlilik, sığınmacıların iş piyasasına erişimi için anahtar rol oynamaktadır. Eğitim ile ilgili olarak öncü verilerin olması (kurumsal ya da araştırmalar dahilindeki veriler), yeteneklerin bilinmesi açısından önemli olsa da bu tür verilerin ülkelerde düzenlenmesi ve depolanması çok nadir yapılmaktadır. Bundan dolayı mesleki ön değerlendirme açısından veri merkezinin oluşturulması ve potansiyel iş eşleştirmelerinin yapılması için önerilebilir. 
- Kurum, kuruluş ve sivil toplum kuruluşları arasında sistematik ve efektif iş birliğinin olması gerekmektedir. Birimler arasındaki görev dağılımının netleşmesi, görev dağılımının belirlenmesi ve çıktılar ile ilgili eylem planlarının hazırlanması gerekmektedir. Yukarıda verilerin öneminden bahsedilmiştir. $\mathrm{Bu}$ kapsamda veri paylaşımlarında koordinasyonların kurulması için gerekli anlaşmaların yapılması gerekmektedir.

- Mesleki eğitim programları ile ilgili olarak yaygınlaştırmaların yapılması gerekmektedir. Ancak bunu yaparken sığınmacıların iş bilgisinin düzeyine bakılması önem arz etmektedir. Bu bağlamda ön değerlendirme yapılarak düşük yetenekli kişilerin, çok yetenekli kişilerden ayrılarak ona göre eğitim prosedürlerinin uygulanması gerekmektedir. Aynı zamanda grupların psiko-sosyal destek birimi personeli tarafından takip edilmesi ve eğitimlerini yarıda bırakan kişiler ile ilgili değerlendirmeler ve tekrar işe döndürme çalışmaları yapılmalıdır.

- Diğer bir önemli nokta ise işverenler ile olan koordinasyondur. İş bulma kurumlarının özellikle işverenler ile aktif ve sürekliliği olan bir iletişimde bulunmaları gerekmektedir. İş bulma biriminin bu konudaki başarısı iş verenlerin sığınmacıları çalıştırmaya istekli hale gelmeleri ile mümkündür. Bu bakımdan meslek eşleştirmeleri ya da işverenin ihtiyaç duyduğu alandaki talebinin aktif olarak takip edilmesi gerekmektedir.

- İşverenler ile en iyi iletişim kurma yolu hangi sektörlerde işçi açı̆̆ının olduğunun öğrenilmesi ve finansal teşviklerin sağlanmasıdır. Finansal teşvik ile kast edilen durumlar işçi ücretleri için devlet desteği, eğitim avantajları, iş yerindeki beceriyi değerlendirmeye bağlı tazminatlardır. İş bulma kurumlarında yapılacak uyum puanlama sistemi ile sığınmacı bazında teşviklerin çeşitlendirilmesi yapılabilir. İş bulma kurumları ile işverenler arasında iletişimin olması işverenlerin beklentilerinin anlaşılmasının yanında sürdürülebilir iş kaynakları açısından önemli bir faktördür. 
EXTENDED ABSTRACT

\title{
The Experiences of Turkmen Workers' Access to Labor Market in the Context of Mass Influx, Social Acceptance and Adaptation
}

\author{
Mustafa Karataş- Veli Duyan \\ Sabahattin Zaim University-Ankara University
}

The study aims to learn with a mass influx from northern Iraq to Turkey Turkmen work experience, to understand their coping strategies, compliance, due diligence is to make the scope of social acceptance of concepts. In the study conducted qualitative research utilizing the method of work experience lived, ages 18 and older, with a mass influx came to Turkey with 40 Turkmen forms, semi-structured interviews have seen the application forms were applied.As a result of the research, it was observed that the participants had a desire to quickly access the labor market due to the adverse situations they experienced during the migration phases, mainly because they encountered severe economic problems when they came to the target country. The existence of more than one social problem has also been identified in the Turkmen's work experience.

The main outputs regarding the work experience of the Turkmen in Turkey are their access to the labor market, their work experience, their occupations, their work experiences and the positive and negative sides of these experiences. When we look at the branches of profession, it is seen that the jobs that do not require education or that can be learned on the job are chosen. It is seen that Turkmens, who generally work as assistants in business branches, especially prefer package transportation services.

Having a sustainable working life ensures stability in the family economy. However, it can be seen that Turkmen quit their jobs for various reasons. The problem of asylum seekers with regard to business life in the global sense is the low wages or the unfair distribution of wages. The most important reason for low wages is unregistered work. Fair wages can be a problem because employers want to reduce costs, are not fully aware of the procedures for employing foreign workers, and are not aware of the incentives within the scope of vocational training programs regarding 
registered and insured employment of foreign workers. Considering the low wages and low earnings, it is seen that Turkmens do not receive a standard wage.

The outputs obtained as a result of the research on business life were evaluated as dissatisfaction with the profession, dissatisfaction arising from the work environment, lack of vocational training and information. Therefore, Turkmens are dissatisfied with their profession, field of work and professional inadequacy. When these negativities are examined, it can also be seen that they overlap with the reasons for leaving the job. However, in some cases, it has been understood that Turkmens, who are in economic distress, have to continue working, no matter how unfavorable they work. According to the results of this research, jobrelated dissatisfaction is the existence of heavy work conditions, the concerns caused by not being able to learn the address, low wages, lack of leave, not getting along, lack of social activity, fear of being unemployed, and lack of job continuity.

Workplace dissatisfaction outcomes are ill-treatment and lack of fair treatment. Turkmens have been subjected to verbal and sometimes physical treatment of business owners and people working in the workplace. At the same time, when they made a mistake, their salaries were cut and their leave revoked. The fact that Turkmens have technology addictions (mobile phones, etc.) has caused this situation to gain dislike in the workplace and their relations with the workplace have been in trouble due to unnecessary use. Turkmens, who think that they experience discrimination especially because they are foreigners, were given difficult jobs in general and double standards were applied with the employees at the workplace.

Obtaining positive results regarding the job market of asylum seekers and conducting follow-up studies require effective migration management. In this context, registration processes should be carried out effectively and efficiently. Providing sustainable job opportunities and regulating employment markets are of great importance. Shortly after the asylum seekers arrive in the target country, there are requests for access to the labor market and problems may be encountered within the scope of finding a job and job sustainability. In this context, the effects of personal and environmental conditions can be seen. In some cases, it can be seen 
that there are problems in accessing the labor market due to the fact that asylum seekers are not given a status. Therefore, due to the high number of applications in some countries, alternative working arrangements can be made. Such arrangements should be made for participation in working life and the formation of the registered labor market by making general evaluations.

It is understood that if favorable conditions are provided in the business life of the Turkmen, there will be more convenient in terms of social acceptance and harmony. In general, it was observed that asylumseekers with language difficulties could not adapt to finding employment and everyday living conditions. Providing sustainable job opportunities, ensuring environment-person compliance, and creating employment services specifically for asylum seekers are of great importance.

\section{Kaynakça / References}

Akcan, A. (2018). Türkiye işgücü piyasasında Suriyeli sığınmacıların yeri ve etkileri. Sosyal Güvenlik Dergisi, 8(2), 59-73.

Aslan, G, ve Güngör, F. (2019). Suriyeli sığınmacıların Türkiye'ye göç sonrası yaşadığı sorunlar: İstanbul örneği. Uluslararası Toplum Araştırmaları Dergisi, 1(18),1604-1632. DOİ: 10.26466/opus.558512.

Bahadır, H. ve Dermiral, Y. (2019) Suriye'den Türkiye'ye zorunlu göç hareketi ve çocuk işçiliği. ESTÜDAM Halk9 Sağhlğı Dergisi, 4, 389- 397. DOİ: https://doi.org/10.35232/estudamhsd.566939.

Birleşmiş Milletler Mülteci Yüksek Komiserliği, (2017). Uluslararası Çalışma Örgütü, Birleşmiş Milletler Çocuklara Yardım Fonu, Child labour within the Syrian refugee response: A regional strategic framework for action, Erişim Adresi: [https://www.refworld.org/docid/5a74728d4.html] Erişim Tarihi: 14/12/2019.

Dedeoğlu, S. (2011). Türkiye'de göçmenlerin sosyal dışlanması: İstanbul hazırgiyim sanayiinde çalışan Azerbaycanlı göçmen kadınlar örneği. Ankara Üniversitesi SBF Dergisi, 66, 27-48, DOİ: 10.1501/SBFder_0000002193.

Demirbaş, B. ve Akyiğit, H. (2018), Suriyeli mülteci kadınların entegrasyon sürecinde sosyal ağların olumlu ve olumsuz etkileri. Muhakeme Dergisi, 1,123-133.

Diker, E. ve İçduygu, A. (2017). Türkiye'deki Suriyeli mültecilerin işgücü piyasası entegrasyonu: Mültecilikten göçmenliğe, 3(1), 12-35. 
Dwyer, P., Hodkinson, S, Lewis, H. and Waite, L. (2016). Socio-legal status and experiences of forced labour among asylum seekers and refugees in the UK. Journal of International and Comparative Social Policy, 32, 182-198. DOI: 10.1080/21699763.2016.1175961.

Ermumcu, S. (2013). Sığınmacıların ve mültecilerin sosyal güvenlik hakkı. Çalışma İlişkileri Dergisi, 4, 58-76.

Gemici-Birinci, N. (2016) Çalışma hayatında dezavantajlı bir grup: Göçmenler. İs ve Hayat, 2, 239 - 261.

Gündüz, A. ve Kalaycı, İ. (2016). Saddam döneminde Türkmen göçleri. Ortadoğu'da Türkmenler (Irak-Iran-Suriye) Sempozyumu, (Ed: Abdulhalik BAKIR- Ahmet ALTUNGÖK), Bilecik.

Harunoğulları, M. (2016). Suriyeli sığınmacı çocuk işçiler ve sorunları: Kilis örneği. Göç Dergisi, 3, 29-63, DOİ: 10.33182/gd.v3i1.554.

Hooper, K., Desiderio, M. V. and Salant B, (2017). İmproving the labour market integration of migrants and refugees, empowering cities through better use of EU instruments, Migration Policy İnstitute.MPİ Europe: 2017.

World Migration Report, (2020). İnternational Organization Of Migraiton 2020. International Labour Organization Global Estimates on International Migrant Workers, (2017), International Labour Organization, Third Edition.

Karataş, M. (2015). Türk Yazılı basınında Suriyeli sığınmacılar ile halk arasındaki ilişkinin incelenmesi. Göç Araştırmaları Dergisi, 1,112-151.

Karslı, B. (2013). Toplumsal birlikteliklerde öncelikler: Kabullenme ve dişlamanın sosyo-psikolojik temelleri (Alevilik-sünnilik örneği). Birey ve Toplum Sosyal Bilimler Dergisi, 3, 99-136.

Kaygısız, İ. (2017). Suriyeli mültecilerin Türkiye iş gücü piyasasına etkileri. Friedrich-Ebert-Stiftung (FES) yayınları. İstanbul:FES, s.16-18.

Khawaja, W., Nigar G., Katherine, M., Schewitzer, R., Greenslade, R. and Jaimi, H., (2008) Difficulties and coping strategies of Sudanese refugees: A qualitative approach. Transcultural Psychiatry, 45(3), 489-512.

Kone, Z., Ruiz, İ. ve Silva, C. V. (2019). Refugees and the UK labour market, Center on Migration And Policy, University Of Oxford.

Lodovici, M. S. (2010). Making a success of integrating immigrants in the labour market, Peer Review, Discussion paper.

Mong, N. S. and Roscigno V. C. (2009). African American men and the experience of employment discrimination. Qualitative Sociology, 33(1), 1-21, DOİ: 10.1007/s11133-009-9142-4. 
OECD, (2017), G20 Global Displacement And Migration Trends Report. Erişim Adresi:https://www.oecd.org/g20/topics/employment-and-social-policy/G20OECD-migration.pdf. Erişim Tarihi: 27/03/2020.

Sezgin A. A. ve Yolcu, T. (2016). Göç ile gelen uluslararası öğrencilerin sosyal uyum ve toplumsal kabul süreci. Humanitas Uluslararası Sosyal Bilimler Dergisi, 4, 419-438, DOI: 10.20304/husbd.14985.

Smith J. A. and Eatough. V. (2007). Interpretative phenomenological analysis. In E. Lyons ve A. Coyle (Eds.). Analysing Qualitative Data In Psychology. p.35-50. Los Angeles: SAGE Publications.

Taşdemir, N. (2017). Göçmenler arasında algılanan ayrımcılık, psikolojik iyi olma hali ve sosyal kimlikler ilişkisinin değerlendirilmesi. Sinop Üniversitesi Sosyal Bilimler Dergisi, 1, 47-70.

Wang, W. W. and Fan, C. C. (2012). Migrant workers' integration in urban China: Experiences in employment, social adaptation, and selfidentity. Eurasian Geography and Economics, 53(6), 731-749.

\section{Kaynakça Bilgisi / Citation Information}

Karataş, M. ve Duyan, V. (2021). Kitlesel göç, sosyal kabullenme ve uyum bağlamında Türkmen işçilerin deneyimleri. OPUS- Uluslararası Toplum Araştırmaları Dergisi, 18(42), 5480-5515. DOI: 10.26466/opus.932531. 